Article

\title{
Corporate Social Responsibility and Post Earnings Announcement Drift: Evidence from Korea
}

\author{
Hyunjung Choi ${ }^{1}$ and Haeyoung Ryu ${ }^{2, *}$ \\ 1 College of Global Business and Technology, Sungkyul University, Anyang-si 14097, Korea; \\ hjchoi@sungkyul.ac.kr \\ 2 Department of Business Administration, Hansei University, Gunpo-si 15852, Korea \\ * Correspondence: hyryu@hansei.ac.kr
}

Citation: Choi, H.; Ryu, H.

Corporate Social Responsibility and Post Earnings Announcement Drift: Evidence from Korea. Sustainability 2021, 13, 6496. https://doi.org/ $10.3390 /$ su13116496

Academic Editor: Sebastian Kot

Received: 26 April 2021

Accepted: 3 June 2021

Published: 7 June 2021

Publisher's Note: MDPI stays neutral with regard to jurisdictional claims in published maps and institutional affiliations.

Copyright: (c) 2021 by the authors. Licensee MDPI, Basel, Switzerland. This article is an open access article distributed under the terms and conditions of the Creative Commons Attribution (CC BY) license (https:// creativecommons.org/licenses/by/ $4.0 /)$.

\begin{abstract}
To promote corporate social responsibility (CSR) in emerging markets such as South Korea to the level of developed nations, support from capital market investors is necessary. That is, CSR activities expand if capital market investors actively invest in companies that pursue such activities. This study thus analyzes the influence of the level of CSR activities on the post-earningsannouncement drift (PEAD) of publicly listed companies in South Korea, given the need to analyze the relationship between capital markets and CSR, which is part of sustainability management strategies. A sample of Korean firms listed on the Korean Stock Exchange from 2014 to 2018 was used for the regression analysis. The financial and stock return data were extracted from the KIS-Value database and CSR activities data were collected from the Korea Economic Justice Institute (KEJI) Index. The empirical analysis determined that more inactive companies in terms of CSR exhibited greater PEAD magnitude. Furthermore, high information asymmetry was found to further increase the magnitude of PEAD. These results indicate that investors cannot make swift investment decisions because of their low confidence in the information disclosed by inactive CSR companies; as a result, earnings information is slowly reflected in the stock prices of the period following disclosure. These findings suggest that CSR plays an important role in boosting investor confidence in corporate earnings information.
\end{abstract}

Keywords: corporate social responsibility; KEJI index; post earnings announcement drift; emerging market

\section{Introduction}

Initially, companies perceived corporate social responsibility (CSR) simply as philanthropy. However, as stakeholders showed growing interest in their firms' social responsibility, companies began to strategically plan CSR activities and increase their scale. Moreover, companies adopt CSR as a means of achieving sustainable growth in a fast-changing business environment. Capital market investors are also interested in the social responsibility of companies and tend to invest more in those actively involved in CSR. Hence, CSR has emerged as a criterion for evaluating companies.

Since the International Organization for Standardization (ISO) developed and published its international standards and guidelines on social responsibility in 2010 [1], companies have been required to disclose information on their CSR activities more transparently. Accordingly, the Global Reporting Initiative (GRI) published guidelines for sustainability reporting and the GRI Standards in 2016 [2]. The GRI Standards describe the corporate economic, environmental and social performance from a sustainability perspective and encourage companies to disclose the impacts of their CSR activities. In Korea, the Korea Economic Justice Institute (KEJI) measures and evaluates firms' CSR activities. The KEJI Index has been providing official CSR ratings for firms listed on the Korea Stock Exchange since 1991 by selecting the top 200 firms every year and disclosing their CSR performance. 
The post-earnings-announcement drift (PEAD) is a phenomenon under which stock prices move in the same direction as unexpected earnings following an earnings announcement [3-5]. Under the efficient market hypothesis, stock prices immediately and fully reflect firm information; hence, the behavior of stock prices following an earnings announcement should be unrelated to the earnings information disclosed by the firm [6]. However, extant studies have identified the existence of PEAD and analyzed the causes of this market anomaly. They found that PEAD occurs when capital market investors cannot properly understand accounting information $[7,8]$ and that more transparent unexpected earnings information further mitigates PEAD [9]. In summary, PEAD manifests differently depending on the transparency of accounting information and on investors' understanding of and confidence in the disclosed information.

A firm actively conducting CSR fulfills legal and ethical responsibilities based on a transparent and honest corporate culture. At the same time, the sense of ethics and social responsibility of senior management are reflected in a firm's accounting information. Previous studies have reported that the firms actively involved in CSR have a higher quality of accounting information and lower information risk and, thus, pay lower capital costs $[10,11]$. If a firm's CSR can build the investors' confidence in the disclosed earnings information and lead investors to evaluate its information transparency more highly, then investors will make faster investment decisions and earnings information will be instantly reflected in the stock price, thereby reducing the PEAD. Thus, this study examined whether firms that are more actively involved in CSR exhibit a lower magnitude of PEAD.

To promote CSR in emerging markets, such as South Korea, to the level of developed nations, support from capital market investors is necessary. That is, CSR activities expand if capital market investors invest actively in the companies that pursue CSR. Given the need to analyze the relationship between capital markets and CSR, which is part of sustainability management strategies, this study investigates how the CSR level influences PEAD among publicly listed companies in South Korea.

The remainder of this article is organized as follows. The next section discusses the prior literature and the development of the hypothesis. The research methodology is presented in Section 3. Section 4 provides the results of the analysis, and Section 5 concludes the article.

\section{Literature Review and Hypotheses Development}

\subsection{Corporate Social Responsibility}

Previous studies of CSR have suggested several conflicting theories regarding the relationship between CSR, financial performance, and corporate value. From the agency theory perspective, CSR activities are understood as incurring costs that are contrary to the goal of maximizing shareholder value. Supporters of agency theory perceive CSR activities as corporate consumption activities directed toward pursuing the private interests of managers. Related studies argue that as the level of CSR activity increases, the financial performance and value of companies are diminished, and these companies show negative (-) share price returns [12-15].

In contrast, according to stakeholder theory, the goal of managers is not only to maximize shareholder profits, but also to conduct management that encompasses all stakeholders who may be affected by the achievement of the company's goals [16]. Accordingly, CSR activities can be used as a tool to manage the conflicting relationships among stakeholders, increase shareholder value, motivate the members of the organization, reduce litigation costs, and prevent the deterioration of public opinion externally $[17,18]$. In addition, corporate social responsibilities as a brand-value-enhancing tool can contribute to sales growth [19]. Regarding the impact on capital markets, a prior study found that the stock price of companies that participated in CSR activities declined relatively less than those that did not participate in such activities, and the abnormal rate of return was high when incorporated into the social index [20]. 
There is also a neutral view of the relationship between CSR and corporate values. From this perspective, CSR activities have a positive effect on corporate value up to a certain level, whereas beyond a certain level, such activities have a negative effect on corporate value [21-23].

Recent studies have analyzed the effect of CSR from the perspective of investors in capital markets. Investors are known to refer to the CSR performance of companies when there are multiple similar investment opportunities [24]. Companies also consider the level of interest of investors when determining their own level of investment in CSR activities [25].

\subsection{Post-Earnings-Announcement Drift}

As previously mentioned, PEAD is a phenomenon under which abnormal returns move in the same direction as unexpected earnings in the period following an earnings announcement. It is thus a market anomaly that manifests as either positive excess returns on positive unexpected earnings or negative excess returns on negative unexpected earnings in the post-announcement period.

In an efficient market, the movement of stock prices in the post-announcement period should be unrelated to the disclosed earnings information [6]. However, numerous studies have identified the existence of PEAD, under which stock prices move in the same direction as the unexpected earnings, and investigated the cause of this phenomenon. Specifically, Foster et al. [26] argued that PEAD is caused by inefficiencies in capital markets, while Bernard and Thomas [7] reported that PEAD occurs because market investors do not properly understand the earnings information disclosed by companies. Abarbanell and Bernard [8] also noted that PEAD occurs when investors fail to fully understand disclosed earnings information and immediately make investment decisions. In addition, Vega [27] argued that information-based trading, as opposed to noise trading, leads to a lower PEAD.

The existence of PEAD has also been identified in the Korean stock market. Notably, PEAD is prominent in companies with low-quality accounting information and high information asymmetry. This is because investors take longer to make investment decisions due to the lower the credibility of the disclosed information (e.g., due to a reliance on private information); thus, earnings information is slowly reflected in the stock price in the postannouncement period [28]. Furthermore, Lee et al. [29] argued that disclosing management forecasts alleviates PEAD. Specifically, they found that PEAD decreased for companies that disclosed management sales forecasts and for more accurate forecasts. Based on these findings, the authors argued that disclosing preliminary accounting information, such as management forecasts, helps improve investors' understanding of earnings information, thus contributing to reducing PEAD.

\subsection{Hypotheses Development}

Focusing on CSR, which influences the transparency of corporate information and capital market investors' confidence in such information, this study investigates whether the firms that are more inactive in terms of CSR show a larger PEAD magnitude. CSR refers to the interaction between a company and society, which encompasses corporate ethics, governance, and its contributions to the local communities. The IFAC [30,31] defined CSR as "sustainability" from an accounting perspective because it can originate from the compliance with accounting-related laws and systems and the delivery of transparent accounting information. CSR also reflects corporate values and culture and influences management's decision-making [32,33]. The managers of companies actively involved in CSR are more likely to make decisions consistent with the company's values, such as providing reliable accounting information rather than pursuing personal interests through earnings management. Indeed, the companies active in CSR have been reported to comply with laws and regulations and not engage in earnings management [34,35]. Therefore, the firms actively involved in CSR provide higher quality accounting information, allowing 
investors to understand earnings information more effectively and easily forecast future cash flows based on this information.

Meanwhile, CSR has a mitigating effect on potential conflicts with stakeholders. For example, Feldman et al. [36] reported that investors positively evaluate companies that actively respond to environmental issues and Starks [37] argued that investors perceive the potential risk of companies inactive in CSR as being high. Furthermore, CSR reduces the occurrence of issues that adversely impact enterprise value, such as conflicts with stakeholders, thus reducing investors' perceptions of the risks associated with the company and its cost of raising capital [38]. Therefore, active CSR efforts positively influence investors' perceived risk and the credibility of corporate information, enabling investors to make prompt decisions based on the disclosed information.

Given that CSR has different effects on the transparency of disclosed information and capital market investors' perceived reliability of that information, this study seeks to identify the differences in PEAD according to the CSR level.

Hypothesis 1 . The companies inactive in CSR will experience a greater magnitude of PEAD in the post-announcement period.

Prior studies have reported that PEAD occurs because of market investors' underreaction to unexpected earnings in the presence of high information asymmetry and uncertainty $[39,40]$. Specifically, PEAD is less prominent in large companies than in small and mid-sized ones because the former provide more information to investors [26]. Additionally, providing management forecast information in proportion to the degree of information uncertainty significantly reduces PEAD [29].

Companies' awareness of CSR positively influences their information environment. Those active in CSR voluntarily disclose more information to stakeholders to promote their corporate image [11], which improves information transparency and reduces information asymmetry [41]. Meanwhile, firms manage earnings in an effort to balance their profit fluctuations to provide consistent earnings among reporting periods [42]. Kim et al. [34] reported that the CSR levels are negatively correlated with discretionary accrual earnings management and real earnings management. They also argued that the values of the companies that pursue CSR are reflected in their accounting information, ultimately reducing information asymmetry.

By disclosing more information, the companies active in CSR can reduce capital market investors' costs of obtaining information. Furthermore, the transparent accounting information provided by a company improves investors' understanding of that information. Therefore, information disclosure practices and efforts to provide transparent accounting information in CSR-active companies positively influence their information environment, encouraging investors to promptly respond to earnings information. In contrast, if companies with high information asymmetry do not actively conduct CSR, which can reduce information uncertainty, even more prominent capital market anomalies will appear.

Hypothesis 2. In the presence of high information asymmetry, companies inactive in CSR will exhibit greater PEAD magnitude.

\section{Research Design}

\subsection{Sample Selection}

A sample of Korean firms listed on the Korean Stock Exchange from 2014 to 2018 was used for the analysis. The financial and stock return data were extracted from the KISValue database provided by Korea Investors Services. The scores related to CSR activities were collected using the KEJI Index, as reported by the Institute of Economic Justice, which is affiliated with the Citizens' Coalition for Economic Justice, and the data on the number of financial analysts and the forecasts of financial analysts were extracted from FnGuide's DataGuide. Additionally, the corporate governance variables and the date of shareholders' convocations were collected manually from the Financial Supervisory Service's Electronic Disclosure System (DART System). Companies with their accounts 
closing in December were included and financial institutions were excluded. Finally, to eliminate the effect of outliers, the sample defined by the top and bottom $1 \%$ of the independent and dependent variables was Winsorized. This sample selection process yielded 1597 firm-year observations.

\subsection{Regression Model}

To investigate the impact of CSR on PEAD, an extension of the regression model of Lee et al. $[28,29]$ was assessed:

$$
C A R_{i t}(n)=\beta_{0}+\beta_{1} S U E+\beta_{2} S I Z E+\beta_{3} L E V+\beta_{4} M B+\beta_{5} D A+\beta_{6} A N A L+\text { Industry\&Year Dummy }+\epsilon
$$

To verify Hypothesis 1, Equation (1) was analyzed by dividing the entire sample into a group that actively conducted CSR (CSR firms) and a group that did not (Non-CSR firms). CSR firms were identified as firms included in the list of the top 200 best corporate citizens, as elaborated by a leading Korean CSR institution, the Korean Economic Justice Institute (KEJI); this is similar to the KLD Index (Kinder, Lydenberg and Domini Research and Analytics, Inc.) in the U.S. The KEJI index is based on quantitative and qualitative measures organized into seven major categories, namely environment, community, corporate governance, corporate integrity, customer satisfaction with product quality and safety, employee relations, and long-term orientation. Through the evaluation process, KEJI announces the top 200 companies with high evaluation scores. In this study, companies listed in the top 200 were defined as CSR firms that actively conduct CSR.

In Equation (1), CAR measures the cumulative abnormal returns after the annual earnings announcement. Specifically, CAR(n) is the sum of the daily abnormal returns of a firm over the $n$ days starting from the day after the earnings announcement $[29,43,44]$. Additionally, CAR over 30,60, 90, and 120 trading day intervals was computed to examine whether the drift existed over longer periods. The daily abnormal returns were calculated as the difference between the daily returns of a firm and the daily market adjusted return using the value weighted index. SUE represents the standardized unexpected earnings. SUE was measured by subtracting consensus one-month-ahead analyst forecasts of earnings per share from actual earnings per share and dividing by the adjusted closing stock price [29,45].

A set of control variables that affect PEAD were employed. Based on previous studies $[28,29,43,44]$, the larger the size of the company, the smaller the debt ratio, and the larger the number of financial analysts, the lower the excess return after disclosure. Firm size (SIZE), financial leverage (LEV), and the number of analysts following a firm (ANAL) were included as control variables, whose regression coefficients were expected to have a negative value. The higher the growth potential, the higher the earnings response coefficient, so the growth potential has an inverse relationship with the market's underreaction. Accordingly, the market-to-book value (MB) was included as a control variable, whose regression coefficient was expected to be negative. Soffer and Lys [9] reported that if transparency about disclosed profits is secured, delays in decision-making by investors are reduced and the phenomenon of PEAD is also reduced. That is, if the accounting transparency is not properly secured, it is difficult for investors to make an appropriate evaluation of the corporate value, and in this case, decisions are more dependent on private information than on public information, which intensifies PEAD [28,29]. As an accounting transparency variable, performance-matched quantitative accruals obtained from Kothari et al. [46] were used as a control variable, whose regression coefficient was expected to be positive. Finally, the model was adjusted for fixed effects of year and industry.

To test Hypothesis 2, Equation (1) was verified by dividing the sample into a group of firms with and without CSR activities and a group with high and low information asymmetry, respectively. Information asymmetry is measured as follows. First, if a firm's size was smaller than the median company size, it was classified into a group with high information asymmetry. Second, if the median of the ratio of the market value to the book value of capital was greater than the median, the company was classified into a group with high information asymmetry [47]. 


\section{Empirical Results}

Table 1 shows the descriptive statistics of the variables used in this study. The mean CAR values over the 30-, 60-, 90-, and 120-day periods (CAR(30), CAR(60), CAR(90), and CAR(120), respectively) after the notice of an annual shareholder meeting were 0.013 , $0.025,0.017$, and 0.018 , and the median values were $-0.002,-0.002,-0.018$, and -0.016 , respectively. Therefore, most of the sample firms had negative returns. The mean and median of standardized unexpected earnings (SUE) were 0.027 and 0.000 , respectively. The mean of DCSR, which shows whether the firm was active in CSR, was 0.322, indicating that $32 \%$ of the sample firms were included in the list of the top 200 best corporate citizens. The mean (median) values of the natural logarithm of the total assets (SIZE), debt ratio (LEV), market-to-book ratio (MB), and absolute value of discretionary accruals (DA) were 27.622 (27.354), $0.395(0.395), 1.366(1.105)$, and $0.040(0.032)$, respectively. The average number of analysts for each firm was 6.574 .

Table 1. Descriptive statistics.

\begin{tabular}{cccccc}
\hline Variables & Mean & Q1 & Median & Q3 & Std. Dev. \\
\hline CAR(30) & 0.013 & -0.089 & -0.002 & 0.095 & 0.184 \\
CAR(60) & 0.025 & -0.131 & -0.002 & 0.151 & 0.267 \\
CAR (90) & 0.017 & -0.180 & -0.018 & 0.167 & 0.312 \\
CAR(120) & 0.018 & -0.199 & -0.016 & 0.195 & 0.357 \\
SUE & 0.027 & -0.039 & 0.000 & 0.059 & 0.042 \\
DCSR(\%) & 0.322 & 0.000 & 0.000 & 1.000 & 0.467 \\
SIZE & 27.622 & 26.561 & 27.354 & 28.675 & 1.260 \\
LEV & 0.395 & 0.237 & 0.395 & 0.548 & 0.174 \\
MB & 1.366 & 0.732 & 1.105 & 1.789 & 0.804 \\
DA & 0.040 & 0.014 & 0.032 & 0.061 & 0.030 \\
ANAL (number) & 6.574 & 0.000 & 3.000 & 12.000 & 7.623 \\
\hline
\end{tabular}

The variables are defined in Appendix A Table A1.

Table 2 presents the Pearson correlation coefficients of the variables. The results indicate that firms with a large size (SIZE), low leverage ratio (LEV), high growth potential $(\mathrm{MB})$, and a large number of financial analysts (ANAL) were more active in CSR. Meanwhile, a positive correlation was observed between SUE and CAR over the different time periods (CAR(30), CAR(60), CAR(90), CAR(120)), albeit not statistically significant. As a bivariate analysis alone is insufficient for systematic hypothesis testing, a multivariate analysis was also performed, which adjusted for variables associated with $C A R$.

Table 2. Correlation coefficients.

\begin{tabular}{|c|c|c|c|c|c|c|c|c|c|c|c|}
\hline & CAR(30) & CAR(60) & CAR(90) & CAR(120) & SUE & DCSR & SIZE & LEV & MB & DA & ANAL \\
\hline CAR(30) & 1.000 & & & & & & & & & & \\
\hline CAR(60) & $0.716^{* * *}$ & 1.000 & & & & & & & & & \\
\hline CAR(90) & $0.553^{* * *}$ & $0.847^{* * *}$ & 1.000 & & & & & & & & \\
\hline CAR(120) & $0.500 * * *$ & $0.751^{* * *}$ & $0.878^{* * *}$ & 1.000 & & & & & & & \\
\hline SUE & 0.045 & 0.039 & 0.004 & 0.006 & 1.000 & & & & & & \\
\hline DCSR & $0.064^{* * *}$ & $0.042 *$ & 0.005 & 0.005 & 0.150 & 1.000 & & & & & \\
\hline SIZE & $0.048^{* *}$ & $0.086^{* * *}$ & 0.043 * & 0.040 * & $-0.146^{* * *}$ & $0.128^{* * *}$ & 1.000 & & & & \\
\hline LEV & $-0.046^{*}$ & 0.025 & -0.006 & 0.002 & $0.116^{* * *}$ & $-0.191 * * *$ & $0.234^{* * *}$ & 1.000 & & & \\
\hline MB & $0.053^{* *}$ & 0.041 * & $0.082 * * *$ & $0.049 * *$ & $0.102 * * *$ & $0.275^{* * *}$ & $0.099 * * *$ & 0.000 & 1.000 & & \\
\hline DA & -0.016 & -0.025 & -0.024 & -0.018 & $0.037 *$ & 0.024 & $-0.083^{* * *}$ & 0.032 & $0.159^{* * *}$ & 1.000 & \\
\hline ANAL & $-0.050 * *$ & $-0.068^{* * *}$ & -0.024 & -0.030 & -0.035 & $0.238^{* * *}$ & $0.760 * * *$ & $0.090 * * *$ & $0.199 * * *$ & -0.016 & 1.000 \\
\hline
\end{tabular}

The variables are defined in Appendix A Table A1. ${ }^{*}, * *$, and ${ }^{* * *}$ denote statistical significance at the $0.10,0.05$, and 0.01 levels, respectively, based on two-tailed tests.

Table 3 presents the results of relevance to Hypothesis 1 . CAR was calculated as the sum of all abnormal returns over the 30-, 60-, 90-, and 120-day periods after an earnings announcement. All models demonstrated F values significant at the $1 \%$ level, indicating that they adequately fit the data. 
Table 3. CSR and post-earnings-announcement drift.

\begin{tabular}{|c|c|c|c|c|c|c|c|c|}
\hline & \multicolumn{4}{|c|}{ CSR } & \multicolumn{4}{|c|}{ Non-CSR } \\
\hline & CAR(30) & CAR(60) & CAR(90) & CAR(120) & CAR(30) & CAR(60) & CAR(90) & CAR(120) \\
\hline \multirow{2}{*}{ Intercept } & 0.772 & 0.642 & 1.542 & 0.583 & 0.245 & 0.347 & 0.279 & 0.123 \\
\hline & $(1.81) *$ & $(2.62)^{* * *}$ & $(2.09)^{* *}$ & $(0.72)$ & $(0.91)$ & $(0.89)$ & $(0.63)$ & $(0.24)$ \\
\hline \multirow{2}{*}{ SUE } & 0.177 & 0.139 & 0.155 & 0.278 & 0.411 & 0.599 & 0.832 & 0.762 \\
\hline & $(0.58)$ & $(0.31)$ & $(0.29)$ & $(0.48)$ & $(2.36) * *$ & $(2.38) * *$ & $(2.89)^{* * *}$ & $(2.29)^{* *}$ \\
\hline \multirow{2}{*}{ SIZE } & 0.028 & 0.056 & 0.054 & 0.017 & 0.009 & 0.010 & 0.011 & 0.003 \\
\hline & $(1.77)$ * & $(2.42)^{* *}$ & $(2.03)^{* *}$ & $(0.56)$ & $(0.90)$ & $(0.70)$ & $(0.64)$ & $(0.17)$ \\
\hline \multirow{2}{*}{ LEV } & -0.127 & -0.164 & -0.196 & -0.201 & -0.119 & -0.088 & -0.012 & -0.041 \\
\hline & $(-1.94) *$ & $(-1.70) *$ & $(-1.72) *$ & $(-1.60)$ & $(-2.62)^{* * *}$ & $(-1.35)$ & $(-0.16)$ & $(-0.49)$ \\
\hline \multirow{2}{*}{ MB } & -0.024 & -0.018 & -0.005 & 0.013 & -0.014 & 0.017 & 0.034 & 0.012 \\
\hline & $(-1.58)$ & $(-0.83)$ & $(-0.19)$ & $(0.44)$ & $(-1.49)$ & $(1.23)$ & $(2.15) * *$ & $(0.67)$ \\
\hline \multirow{2}{*}{ DA } & 0.048 & 0.114 & -0.176 & 0.252 & -0.497 & -0.703 & -0.677 & -0.743 \\
\hline & $(0.15)$ & $(0.24)$ & $(-0.31)$ & $(0.41)$ & $(-2.24)^{* *}$ & $(-2.19)^{* *}$ & $(-1.85) *$ & $(-1.75)$ * \\
\hline \multirow{2}{*}{ ANAL } & 0.005 & 0.007 & 0.006 & -0.001 & 0.001 & 0.001 & 0.001 & 0.002 \\
\hline & $(1.76)$ * & $(1.80) *$ & (1.38) & $(-0.24)$ & $(0.54)$ & $(0.68)$ & $(0.28)$ & $(0.58)$ \\
\hline IND & Included & Included & Included & Included & Included & Included & Included & Included \\
\hline YR & Included & Included & Included & Included & Included & Included & Included & Included \\
\hline Adj. $\mathrm{R}^{2}$ & 0.06 & 0.11 & 0.12 & 0.14 & 0.08 & 0.08 & 0.06 & 0.06 \\
\hline F-value & $2.97^{* * *}$ & $2.75^{* * *}$ & $1.98^{* * *}$ & $2.35^{* * *}$ & $2.98^{* * *}$ & $2.69^{* * *}$ & $1.95^{* * *}$ & $2.23^{* * *}$ \\
\hline Observations & 511 & 511 & 511 & 511 & 1086 & 1086 & 1086 & 1086 \\
\hline
\end{tabular}

The variables are defined in Appendix A Table A1. ${ }^{*}{ }^{* *}$, and ${ }^{* * *}$ denote statistical significance at the $0.10,0.05$, and 0.01 levels, respectively, based on two-tailed tests.

The variable of interest in this study was SUE. If the Non-CSR firms experienced a greater magnitude of PEAD, the regression coefficient on SUE was expected to have a significant positive value. The results also revealed positive regression coefficients for SUE in the non-CSR group of 0.411, 0.599, 0.832, and 0.762, respectively, indicating a significant positive correlation with CAR (dependent variable) over the 30-, 60-, 90-, and 120-day periods (CAR(30), CAR(60), CAR(90), CAR(120)). However, for the CSR firms, the regression coefficient on SUE was not significant with CAR over the 30-, 60-, 90-, and 120-day periods. These results support Hypothesis 1, which predicted that the magnitude of PEAD would be larger for the Non-CSR firms compared to the CSR firms. Unreliable accounting information prevents users from promptly and accurately understanding new firm-specific information. Consequently, stock prices drift in the same direction as unexpected earnings, rather than an immediate stock price reaction following an earnings announcement. The results suggest that the CSR level, which reflects a firm's ethics, is related to the transparency of its accounting information. As market investors have low confidence and understanding of the accounting information disclosed by companies inactive in CSR, they cannot immediately react to new earnings information, which explains the large PEAD magnitude.

To test Hypothesis 2, this study investigated how PEAD differed with the level of CSR between the firms with high and low information asymmetry; the results are shown in Tables 4 and 5. Firm size (SIZE) and growth potential (MB) were used as proxy variables for information asymmetry. Table 4 shows the verification of the hypothesis according to the level of information asymmetry based on the size of the company, and Table 5 shows verification of the hypothesis according to the level of information asymmetry based on MB. In Table 4, the CSR and non-CSR groups are shown in Panels A and B, respectively, and the firms are categorized into low and high information asymmetry groups based on the median value of firm sizes, whereby the former is larger and the latter is smaller than the median. According to prior research, larger firms have more stakeholders and provide more information, thus facilitating the use of accounting information. This process can mitigate information asymmetry between firms and investors, thereby reducing the risk premium associated with uncertainty [48]. 
Table 4. CSR and post-earnings announcement drift: Accounting for information asymmetry (Size).

\begin{tabular}{|c|c|c|c|c|c|c|c|c|}
\hline \multicolumn{9}{|c|}{ Panel A: CSR Firms } \\
\hline & \multicolumn{4}{|c|}{ High Information Asymmetry } & \multicolumn{4}{|c|}{ Low Information Asymmetry } \\
\hline & CAR(30) & CAR(60) & CAR(90) & CAR(120) & CAR(30) & CAR(60) & CAR(90) & CAR(120) \\
\hline \multirow{2}{*}{ Intercept } & 0.215 & 0.426 & 0.305 & 0.257 & 0.085 & 0.710 & 0.129 & 0.135 \\
\hline & $(1.74) *$ & $(2.40)^{* *}$ & $(1.49)$ & $(1.13)$ & $(0.17)$ & $(0.91)$ & $(1.33)$ & $(0.13)$ \\
\hline \multirow{2}{*}{ SUE } & 0.596 & 0.371 & 0.443 & 0.580 & 0.519 & 0.208 & 0.542 & 0.425 \\
\hline & $(1.43)$ & $(0.62)$ & $(0.64)$ & $(0.75)$ & $(1.10)$ & $(0.28)$ & $(0.59)$ & $(0.43)$ \\
\hline \multirow{2}{*}{ SIZE } & 0.078 & 0.158 & 0.115 & 0.097 & 0.002 & 0.023 & 0.042 & 0.001 \\
\hline & $(1.68) *$ & $(2.36)^{* *}$ & $(1.49)$ & $(1.13)$ & $(0.11)$ & $(0.82)$ & $(1.19)$ & $(0.02)$ \\
\hline \multirow{2}{*}{ LEV } & -0.230 & -0.298 & -0.303 & -0.363 & -0.019 & -0.031 & -0.095 & -0.096 \\
\hline & $(-2.25)^{* *}$ & $(-2.04)^{* *}$ & $(-1.79)$ * & $(-1.93)^{*}$ & $(-0.26)$ & $(-0.26)$ & $(-0.64)$ & $(-0.61)$ \\
\hline \multirow{2}{*}{$\mathrm{MB}$} & -0.038 & -0.024 & -0.019 & 0.015 & -0.012 & -0.013 & -0.003 & 0.010 \\
\hline & $(-1.61)$ & $(-0.70)$ & $(-0.49)$ & $(0.36)$ & $(-0.64)$ & $(-0.44)$ & $(-0.08)$ & $(0.25)$ \\
\hline \multirow{2}{*}{ DA } & 0.155 & 0.123 & -0.033 & 0.032 & 0.180 & 0.249 & 0.014 & -0.220 \\
\hline & $(0.72)$ & $(0.40)$ & $(-0.09)$ & $(0.08)$ & $(0.80)$ & $(0.71)$ & $(0.03)$ & $(-0.47)$ \\
\hline \multirow{2}{*}{ ANAL } & 0.005 & 0.005 & 0.015 & 0.006 & 0.002 & 0.006 & 0.004 & -0.003 \\
\hline & $(0.77)$ & $(0.58)$ & $(1.52)$ & $(0.58)$ & $(0.80)$ & $(1.46)$ & $(0.77)$ & $(-0.64)$ \\
\hline IND & Included & Included & Included & Included & Included & Included & Included & Included \\
\hline YR & Included & Included & Included & Included & Included & Included & Included & Included \\
\hline Adj. $\mathrm{R}^{2}$ & 0.12 & 0.13 & 0.10 & 0.15 & 0.11 & 0.23 & 0.26 & 0.28 \\
\hline F-value & $2.13^{* * *}$ & $2.21^{* * *}$ & $2.98^{* * *}$ & $2.50^{* * *}$ & $2.90^{* * *}$ & $2.14^{* * *}$ & $2.51^{* * *}$ & $2.73^{* * *}$ \\
\hline Observations & 254 & 254 & 254 & 254 & 257 & 257 & 257 & 257 \\
\hline
\end{tabular}

Panel B: Non-CSR firms

\begin{tabular}{|c|c|c|c|c|c|c|c|c|}
\hline & \multicolumn{4}{|c|}{ High Information Asymmetry } & \multicolumn{4}{|c|}{ Low Information Asymmetry } \\
\hline & CAR(30) & CAR(60) & CAR(90) & CAR(120) & CAR(30) & CAR(60) & CAR(90) & CAR(120) \\
\hline \multirow{2}{*}{ Intercept } & 0.816 & 0.770 & 0.565 & 0.524 & 0.104 & 0.220 & 0.042 & 0.175 \\
\hline & $(0.87)$ & $(0.58)$ & $(0.36)$ & $(0.29)$ & $(0.27)$ & $(0.39)$ & $(0.07)$ & $(0.25)$ \\
\hline \multirow{2}{*}{ SUE } & 0.581 & 0.685 & 0.769 & 0.645 & 0.197 & 0.412 & 0.921 & 0.839 \\
\hline & $(2.10)^{* *}$ & $(1.75)^{*}$ & $(1.66)^{*}$ & $(1.91) *$ & $(0.84)$ & $(1.19)$ & $(2.45)^{* *}$ & $(1.96) *$ \\
\hline \multirow{2}{*}{ SIZE } & 0.029 & 0.028 & 0.019 & 0.019 & 0.003 & 0.006 & 0.001 & 0.005 \\
\hline & $(0.84)$ & $(0.58)$ & $(0.32)$ & $(0.28)$ & $(0.18)$ & $(0.30)$ & $(0.04)$ & $(0.21)$ \\
\hline \multirow{2}{*}{ LEV } & -0.095 & -0.123 & -0.024 & -0.081 & -0.094 & -0.077 & -0.023 & -0.042 \\
\hline & $(-1.22)$ & $(-1.10)$ & $(-0.19)$ & $(-0.53)$ & $(-1.73)$ * & $(-0.97)$ & $(-0.27)$ & $(-0.43)$ \\
\hline \multirow{2}{*}{ MB } & -0.023 & 0.027 & 0.061 & 0.029 & -0.008 & 0.010 & 0.016 & 0.005 \\
\hline & $(-1.31)$ & (1.11) & $(2.09)^{* *}$ & $(0.88)$ & $(-0.69)$ & $(0.55)$ & $(0.86)$ & $(0.24)$ \\
\hline \multirow{2}{*}{ DA } & 0.297 & 0.192 & -0.078 & 0.012 & 0.004 & -0.003 & 0.203 & 0.395 \\
\hline & $(1.67)$ * & $(0.76)$ & $(-0.26)$ & $(0.03)$ & $(0.03)$ & $(-0.01)$ & $(0.90)$ & (1.54) \\
\hline \multirow{2}{*}{ ANAL } & 0.300 & -0.010 & -0.015 & -0.017 & 0.001 & 0.001 & 0.001 & 0.002 \\
\hline & $(0.45)$ & $(-1.36)$ & $(-1.72)^{*}$ & $(-1.67)^{*}$ & $(0.39)$ & $(0.42)$ & $(0.52)$ & $(0.52)$ \\
\hline IND & Included & Included & Included & Included & Included & Included & Included & Included \\
\hline YR & Included & Included & Included & Included & Included & Included & Included & Included \\
\hline Adj. $\mathrm{R}^{2}$ & 0.09 & 0.10 & 0.08 & 0.11 & 0.11 & 0.08 & 0.07 & 0.07 \\
\hline F-value & $2.40 * * *$ & $2.59^{* * *}$ & $2.36^{* * *}$ & $2.90^{* * *}$ & $2.53^{* * *}$ & $2.93^{* * *}$ & $2.58^{* * *}$ & $2.46^{* * *}$ \\
\hline Observations & 441 & 441 & 441 & 441 & 645 & 645 & 645 & 645 \\
\hline
\end{tabular}

The variables are defined in Appendix A Table A1. ${ }^{*}{ }^{* *}$, and ${ }^{* * *}$ denote statistical significance at the $0.10,0.05$, and 0.01 levels, respectively, based on two-tailed tests.

In Table 4, Panel A was verified by dividing CSR firms into groups with high and low information asymmetry levels, and Panel B was verified by dividing non-CSR firms into groups with high and low levels of information asymmetry. Panel A shows insignificant coefficients on SUE for the CSR group over the post-announcement periods (CAR(30), CAR(60), CAR(90), CAR(120)) after the notice of an annual shareholder meeting, irrespective of the degree of information asymmetry. Conversely, Panel B shows significant positive coefficients on SUE in all models in the presence of high information asymmetry. In the group with low information asymmetry, the regression coefficients of SUE were significant 
and positive only for CSR (90) and CSR (120). These results confirm that the Non-CSR firms experienced a greater magnitude of PEAD, especially when their information asymmetry was high. In contrast, the CSR firms exhibited no PEAD, regardless of the level of information asymmetry.

Table 5. CSR and post-earnings announcement drift accounting for information asymmetry $(M B)$.

\begin{tabular}{|c|c|c|c|c|c|c|c|c|}
\hline \multicolumn{9}{|c|}{ Panel A: CSR Firms } \\
\hline & \multicolumn{4}{|c|}{ High Information Asymmetry } & \multicolumn{4}{|c|}{ Low Information Asymmetry } \\
\hline & CAR(30) & CAR(60) & CAR(90) & CAR(120) & CAR(30) & CAR(60) & CAR(90) & CAR(120) \\
\hline \multirow{2}{*}{ Intercept } & 0.444 & 1.868 & 0.212 & 1.346 & 0.561 & 0.273 & 1.518 & 0.533 \\
\hline & $(0.86)$ & $(2.18)^{* *}$ & $(1.98)^{*}$ & $(1.13)$ & $(3.76)^{* * *}$ & $(3.06)^{* * *}$ & $(1.59)$ & $(0.53)$ \\
\hline \multirow{2}{*}{ SUE } & 0.714 & 0.474 & 0.481 & 1.177 & 0.626 & 0.271 & 0.163 & 0.427 \\
\hline & $(1.20)$ & $(0.48)$ & $(0.04)$ & $(0.85)$ & $(1.61)$ & $(0.53)$ & $(0.30)$ & $(0.74)$ \\
\hline \multirow{2}{*}{ SIZE } & 0.018 & 0.069 & 0.074 & 0.046 & 0.085 & 0.093 & 0.051 & 0.015 \\
\hline & $(0.95)$ & $(2.18)^{* *}$ & $(1.90) *$ & $(1.04)$ & $(3.47)^{* * *}$ & $(2.87)^{* * *}$ & $(1.47)$ & $(0.42)$ \\
\hline \multirow{2}{*}{ LEV } & -0.015 & -0.071 & -0.099 & -0.178 & -0.307 & -0.311 & -0.306 & -0.282 \\
\hline & $(-0.19)$ & $(-0.56)$ & $(-0.63)$ & $(-1.01)$ & $(-2.95)^{* * *}$ & $(-2.27) * *$ & $(-2.09) * *$ & $(-1.82) *$ \\
\hline \multirow{2}{*}{ MB } & 0.004 & -0.013 & -0.032 & -0.012 & -0.267 & -0.182 & -0.158 & -0.123 \\
\hline & $(0.19)$ & $(-0.41)$ & $(-0.81)$ & $(-0.26)$ & $(-3.04)$ & $(-1.58)$ & $(-1.28)$ & $(-0.95)$ \\
\hline \multirow{2}{*}{ DA } & -0.103 & -0.104 & -0.335 & -0.272 & 1.110 & 1.386 & 1.151 & 1.224 \\
\hline & $(-0.62)$ & $(-0.38)$ & $(-0.97)$ & $(-0.71)$ & $(3.59)^{* * *}$ & $(3.42) * * *$ & $(2.65) * * *$ & $(2.67)^{* * *}$ \\
\hline \multirow{2}{*}{ ANAL } & 0.003 & 0.007 & 0.008 & 0.001 & 0.012 & 0.014 & 0.008 & 0.003 \\
\hline & $(1.14)$ & $(1.49)$ & (1.39) & $(0.12)$ & $(2.57)^{* *}$ & $(2.25)^{* *}$ & $(1.24)$ & $(0.45)$ \\
\hline IND & Included & Included & Included & Included & Included & Included & Included & Included \\
\hline YR & Included & Included & Included & Included & Included & Included & Included & Included \\
\hline Adj. $R^{2}$ & 0.06 & 0.12 & 0.16 & 0.21 & 0.27 & 0.28 & 0.22 & 0.24 \\
\hline F-value & $2.57^{* * *}$ & $2.21^{* * *}$ & $2.70^{* * *}$ & $2.28^{* * *}$ & $2.32^{* * *}$ & $2.53^{* * *}$ & $2.86^{* * *}$ & $2.99 * * *$ \\
\hline Observations & 280 & 280 & 280 & 280 & 231 & 231 & 231 & 231 \\
\hline
\end{tabular}

Panel B: Non-CSR firms

\begin{tabular}{|c|c|c|c|c|c|c|c|c|}
\hline & \multicolumn{4}{|c|}{ High Information Asymmetry } & \multicolumn{4}{|c|}{ Low Information Asymmetry } \\
\hline & CAR(30) & CAR(60) & CAR(90) & CAR(120) & CAR(30) & CAR(60) & CAR(90) & CAR(120) \\
\hline \multirow{2}{*}{ Intercept } & 0.056 & 0.202 & 0.869 & 0.450 & 0.739 & 1.391 & 0.780 & 1.147 \\
\hline & $(0.15)$ & $(0.36)$ & $(1.27)$ & $(0.58)$ & $(1.93) *$ & $(2.70)^{* * *}$ & $(1.40)$ & $(1.75) *$ \\
\hline \multirow{2}{*}{ SUE } & 0.479 & 1.007 & 1.009 & 0.352 & 0.234 & 0.328 & 0.611 & 0.817 \\
\hline & $(1.54)$ & $(2.07) * *$ & $(1.72) *$ & $(2.13) * *$ & $(1.06)$ & $(1.11)$ & $(1.90) *$ & $(2.16) * *$ \\
\hline \multirow{2}{*}{ SIZE } & 0.001 & 0.006 & 0.029 & 0.017 & 0.022 & 0.045 & 0.026 & 0.040 \\
\hline & $(0.07)$ & $(0.26)$ & $(1.17)$ & $(0.58)$ & $(0.57)$ & $(2.45) * *$ & $(1.30)$ & $(1.69) *$ \\
\hline \multirow{2}{*}{ LEV } & -0.049 & -0.051 & -0.152 & -0.145 & -0.156 & -0.235 & -0.185 & -0.198 \\
\hline & $(-0.81)$ & $(-0.54)$ & $(-1.33)$ & $(-1.12)$ & $(-2.38)^{* *}$ & $(-2.68)^{* * *}$ & $(-1.95)$ * & $(-1.77)$ * \\
\hline \multirow{2}{*}{ MB } & 0.011 & 0.055 & 0.073 & 0.050 & -0.163 & -0.139 & -0.102 & -0.088 \\
\hline & $(0.76)$ & $(2.35) * *$ & $(2.62)^{* * *}$ & (1.57) & $(-2.93)^{* * *}$ & $(-1.85) *$ & $(-1.25)$ & $(-0.92)$ \\
\hline \multirow{2}{*}{ DA } & 0.162 & 0.077 & 0.117 & 0.345 & 0.208 & 0.260 & 0.084 & 0.105 \\
\hline & (1.14) & $(0.34)$ & $(0.44)$ & (1.14) & $(1.20)$ & (1.11) & $(0.33)$ & $(0.35)$ \\
\hline \multirow{2}{*}{ ANAL } & 0.000 & -0.004 & -0.006 & -0.005 & 0.003 & 0.007 & 0.005 & 0.007 \\
\hline & $(0.12)$ & $(-1.08)$ & $(-1.09)$ & $(-1.07)$ & (1.50) & $(2.29) * *$ & (1.47) & $(1.81) *$ \\
\hline IND & Included & Included & Included & Included & Included & Included & Included & Included \\
\hline YR & Included & Included & Included & Included & Included & Included & Included & Included \\
\hline Adj. $R^{2}$ & 0.07 & 0.08 & 0.07 & 0.07 & 0.15 & 0.15 & 0.10 & 0.12 \\
\hline F-value & $2.24^{* * *}$ & $2.42^{* * *}$ & $2.14^{* * *}$ & $2.26^{* * *}$ & $3.36^{* * *}$ & $3.46^{* * *}$ & $2.22 * * *$ & $2.73^{* * *}$ \\
\hline Observations & 469 & 469 & 469 & 469 & 617 & 617 & 617 & 617 \\
\hline
\end{tabular}

The variables are defined in Appendix A Table A1. ${ }^{* * *}$, and ${ }^{* * *}$ denote statistical significance at the $0.10,0.05$, and 0.01 levels, respectively, based on two-tailed tests.

Table 5 shows the results of testing Hypothesis 2, for which a method similar to that in Table 4 was used. In this case, the firms were categorized into the low and high information asymmetry groups based on the median value of $M B$. The literature reports 
that companies with high growth potential (i.e., above the median) have high information asymmetry. This is because their high potential profitability incurs high risk and because it is difficult for external investors to forecast earnings. Accordingly, this study categorized the companies into high and low information asymmetry groups based on their growth potential (MB), such that the former was larger and the latter smaller than the median.

Table 5, Panel A shows insignificant coefficients for the relationship between SUE and CSR over the post-announcement periods (CAR(30), CAR(60), CAR(90), CAR(120)) after the notice of an annual shareholder meeting, irrespective of the degree of information asymmetry. Conversely, Panel B shows significant positive coefficients on SUE in all models in the presence of high information asymmetry. To summarize the above results: PEAD existed in the Non-CSR firms, but not in the CSR firms. In addition, PEAD was not observed in the CSR firms, regardless of the level of information asymmetry, but PEAD manifested differently according to the level of information asymmetry in the Non-CSR firms, especially when information asymmetry was high.

\section{Conclusions}

Companies face diverse and complex issues when dealing with a wide variety of stakeholders such as shareholders, employees, customers, affiliated suppliers, competitors, local communities, and the environment. As such, companies engage in CSR because they risk damage to their competitiveness and sustainability if they do not actively consider and respond to such issues.

Previous studies of the relationship between CSR activities, corporate value, and financial performance have provided mixed results. Recently, studies have begun to analyze CSR from an investor's perspective, but no analysis has been reported regarding how the fulfillment of social responsibility affects the response of investors in capital markets. This study thus investigated how capital market investors perceive the information disclosed by CSR-active companies by testing the relationship between the CSR level and PEAD.

A negative (-) relationship was hypothesized between the level of CSR activity and the degree of PEAD; the results supported that the companies inactive in CSR experienced a greater magnitude of PEAD in the post-announcement period. Furthermore, high information asymmetry increased the magnitude of PEAD. The findings thus indicate that the business ethics of companies pursuing CSR are reflected in the transparency of their accounting information and their disclosure practices, ultimately influencing PEAD.

The results of this study imply that investors in emerging markets such as Korea make quick decisions on profit information disclosed by companies that actively fulfill their social responsibilities. This suggests that supervisory agencies in emerging markets need to promote engagement in CSR activities by granting benefits to companies actively engaged in such activities.

A company's CSR activities can be regarded as a kind of signal, as these are activities that a company carries out with intention that have associated expenses. How do investors in capital markets perceive companies that actively carry out CSR? Specifically, how do capital market investors react to information disclosed by companies that actively conduct CSR? This study helps answer these questions by examining the role of socially responsible activities in capital markets, and specifically the relationship between CSR activities and PEAD.

In emerging markets such as South Korea, the transparency and credibility of the information disclosed to the market are essential to improve investors' understanding of this information and to encourage investment. In this context, PEAD (i.e., when stock prices move in the same direction as unexpected earnings) should be reduced to build investor confidence in the market overall. By verifying the relationship between CSR and PEAD, this study's findings suggest that CSR can play an important role in building the confidence of capital market investors in corporate earnings information.

This study focused on the Korean market as an emerging market in which regulatory management systems, including overseeing authorities, have not been systematically estab- 
lished for CSR activities among businesses, and shareholder protection is also inferior to that of the developed countries [49]. Therefore, caution should be taken when generalizing the results of this study, and verification needs to be conducted in other emerging markets.

Author Contributions: Conceptualization, H.C. and H.R.; methodology, H.C. and H.R.; formal analysis, H.C. and H.R.; writing —original draft, H.C. and H.R.; writing-review and editing, H.C. and H.R.; funding acquisition, H.R. All authors have read and agreed to the published version of the manuscript.

Funding: This work was supported by the Ministry of Education of the Republic of Korea and the National Research Foundation of Korea (NRF-2020S1A5A8041170).

Institutional Review Board Statement: Not applicable.

Informed Consent Statement: Not applicable.

Data Availability Statement: Not applicable.

Conflicts of Interest: The authors declare no conflict of interest.

\section{Appendix A}

Table A1. Variable definitions.

\begin{tabular}{|c|c|}
\hline Variable & Description \\
\hline $\operatorname{CAR}(n)$ & $\begin{array}{l}\text { Cumulative abnormal returns after quarterly earnings announcement. It is equal to the sum } \\
\text { of daily abnormal returns of a firm over the } n \text { days starting from the day after earnings } \\
\text { announcement }(n=30,60,90,120) .\end{array}$ \\
\hline SUE & $\begin{array}{l}\text { Standardized unexpected earnings (actual earnings per share subtracted by consensus } \\
\text { one-month-ahead analyst forecasts of earnings per share/closing stock price). }\end{array}$ \\
\hline DCSR & An indicator variable that takes 1 if the firm is ranked in the KEJI Index, and 0 otherwise. \\
\hline SIZE & Natural logarithm of total assets. \\
\hline LEV & Total liabilities divided by total assets. \\
\hline $\mathrm{MB}$ & Market value divided by book value of shareholders' equity. \\
\hline DA & Absolute value of discretionary accruals obtained from Kothari et al. (2005) [46]. \\
\hline ANAL & Number of analysts following the firm. \\
\hline
\end{tabular}

\section{References}

1. International Organization for Standardization (ISO). ISO 26000 Social Responsibility 2010. Available online: http:/ / www.iso. org/iso/discovering_iso_26000.pdf (accessed on 15 January 2021).

2. GRI Standards. Available online: https://www.globalreporting.org/standards/ (accessed on 20 February 2021).

3. Ball, R.; Brown, P. An empirical evaluation of accounting income numbers. J. Account. Res. 1968, 6, 159-178. [CrossRef]

4. Jones, C.; Litzenberger, R. Quarterly earnings reports and intermediate stock price trends. J. Financ. 1970, 25, 143-148. [CrossRef]

5. Latane, H.; Jones, C. Standardized unexpected earnings: 1971-1977. J. Financ. 1979, 34, 717-724.

6. Fama, E.F. Efficient capital markets: A review of theory and empirical work. J. Financ. 1970, 25, 383-417. [CrossRef]

7. Bernard, V.; Thomas, J. Evidence that stock prices do not fully reflect the implications of current earnings for future earnings. $J$. Account. Econ. 1990, 13, 305-340. [CrossRef]

8. Abarbanell, J.S.; Bernard, V. Tests of analysts' overreaction/underreaction to earnings information as an explanation for anomalous stock price behavior. J. Financ. 1992, 47, 1181-1207. [CrossRef]

9. Soffer, L.; Lys, T. Post-earnings-announcement drift and the dissemination of predictable information. Contemp. Account. Res. 1999, 16, 305-331. [CrossRef]

10. Ashbaugh, H.; Collins, D.; Kinney, W.; Lafond, R. The effect of SOX internal control deficiencies and their remediation on accrual quality. Account. Rev. 2008, 83, 217-250. [CrossRef]

11. Dhaliwal, D.; Hogan, C.; Trezevant, R.; Wilkins, M. Internal control disclosures, monitoring and the cost of debt. Account. Rev. 2011, 86, 1131-1156. [CrossRef]

12. Pava, M.L.; Krausz, J. The association between corporate social and financial performance: The paradox of social cost. J. Bus. Ethics 1996, 15, 321-357. [CrossRef]

13. Wright, P.; Ferris, S.P. Agency conflict and corporate strategy: The effect of divestment on corporate value. Strateg. Manag. J. 1997, 18, 77-83. [CrossRef] 
14. Jensen, M.C. Value maximization, stakeholder theory, and the corporate objective function. Appl. Corp. Financ. 2001, 14, 8-21. [CrossRef]

15. Brammer, S.; Brooks, C.; Pavelin, S. Corporate social performance and stock returns: UK evidence from disaggregate measures. Financ. Manag. 2006, 35, 97-116. [CrossRef]

16. Freeman, R.E. Strategic Management: A Stakeholder Approach; Pitman: Boston, MA, USA, 1984.

17. Heal, G. Corporate social responsibility: An economic and financial framework. Int. Assoc. Study Insur. Econ. 2005, 30, 387-409. [CrossRef]

18. McWilliams, A.; Siegel, D.; Wright, P.M. Corporate social responsibility: Strategic implications. J. Manag. Stud. 2006, 43, 1-18. [CrossRef]

19. Nadanyiova, M.; Durana, P. Corporate social responsibility as a brand value-enhancing tool. In Proceedings of the 8th International Scientific Symposium Economy of Eastern Croatia-Vision and Growth, Osijek, Croatia, 30-31 May 2019; pp. $1225-1237$.

20. Chow, G.W.; Durand, R.B.; Koh, S. Are ethical investments good? Aust. J. Manag. 2014, 39, 645-665. [CrossRef]

21. Borghesi, R.; Houston, J.F.; Naranjo, A. Corporate socially responsible investments: CEO altruism, reputation shareholder interests. J. Corp. Financ. 2014, 26, 164-181. [CrossRef]

22. Cheng, B.; Ioannou, I.; Serafeim, G. Corporate social responsibility and access to finance. Strateg. Manag. J. 2014, 35, 1-23. [CrossRef]

23. Jian, M.; Lee, K.W. CEO compensation and corporate social responsibility. J. Multinatl. Financ. Manag. 2015, 29, 46-65. [CrossRef]

24. Friedman, H.L.; Heinle, M.S. Taste, information, and asset prices: Implications for the valuation of CSR. Rev. Account. Stud. 2016, 21, 740-767. [CrossRef]

25. Naughton, J.P.; Wang, C.; Yeung, I. Investor sentiment for corporate social performance. Account. Rev. 2019, 94, 401-420. [CrossRef]

26. Foster, G.; Olsen, C.; Shevlin, T. Earnings releases, anomalies, and the behavior of security returns. Account. Rev. 1984, 59, 574-603.

27. Vega, C. Stock price reaction to public and private information. J. Financ. Econ. 2006, 82, 103-133. [CrossRef]

28. Lee, K.T.; Lee, Y.J. A study of factors affecting post-earnings-announcement drift. Korean Account. Rev. 2008, 33, 61-101.

29. Lee, K.T.; Lee, Y.J.; Choi, J.W. Effects of management forecasts on post earnings announcement drift. Korean Account. Rev. 2011, 36, 211-248.

30. International Federation of Accountants (IFAC). Professional Accountants in Business: At the Heart of Sustainability? Professional Accountants in Business Committee: New York, NY, USA, 2006.

31. International Federation of Accountants (IFAC). Sustainability: The Role of the Professional Accountant in Business; Professional Accountants in Business Committee: New York, NY, USA, 2006.

32. Aguilera, R.V.; Rupp, D.E.; Williams, C.A.; Ganapathi, J. Putting the S back in corporate social responsibility: A multilevel theory of social change in organizations. Acad. Manag. Rev. 2007, 32, 836-863. [CrossRef]

33. Trevino, L.E. Ethical decision making in organizations: A person-situation interactionist model. Acad. Manag. Rev. 1986, 11, 601-617. [CrossRef]

34. Kim, Y.; Park, M.; Wier, B. Is earnings quality associated with corporate social responsibility? Account. Rev. 2012, 87, 761-796. [CrossRef]

35. Choi, H.J.; Moon, D.C. The relationship between corporate social responsibility and accounting transparency. Korean Account. Rev. 2013, 38, 135-171.

36. Feldman, S.J.; Soyka, P.A.; Arneer, P.G. Does improving a firm's environmental management system and environmental performance result in a higher stock price? J. Investig. 1997, 6, 87-97. [CrossRef]

37. Starks, L.T. Corporate governance and corporate social responsibility: What do investors care about? What should investors care about? Financ. Rev. 2009, 44, 461-468. [CrossRef]

38. El Ghoul, S.; Guedhami, O.; Kwok, C.; Mishra, D. Does corporate social responsibility affect the cost of capital? J. Bank. Financ. 2011, 35, 2288-2406. [CrossRef]

39. Shivakumar, L. Accruals, cash flows and the post-earnings announcement drift. J. Bus. Financ. Account. 2006, 33, 1-25. [CrossRef]

40. Jegadeesh, N.; Livnat, J. Post-earnings-announcement drift: The role of revenue surprises. Financ. Analyst. J. 2006, 62, 22-34. [CrossRef]

41. Chih, H.L.; Shen, C.H.; Kang, F.C. Corporate social responsibility, investor protection, and earnings management: Some international evidence. J. Bus. Ethics 2008, 79, 179-198. [CrossRef]

42. Kliestik, T.; Valaskova, K.; Nica, E.; Kovacova, M.; Lazaroiu, G. Advanced methods of earnings management: Monotonic trends and change-points under spotlight in the Visegrad countries. Oeconomia Copernic. 2020, 11, 371-400. [CrossRef]

43. Nah, C.K.; Shin, H.J. The effects of foreign ownership on the magnitude of the post-earnings-announcement drift. Korean Account. Rev. 2012, 37, 203-238.

44. Nah, C.K.; Shin, H.J. Informativeness of fundamental variables and post-earnings-announcement drift. Korean Account. Rev. 2013, 38, 355-390.

45. Liang, L. Post-earnings-announcement drift and market participants' information processing biases. Rev. Account. 2003, 8, 321-345. [CrossRef]

46. Kothari, S.P.; Leone, A.J.; Wasley, C.E. Performance matched discretionary accrual measures. J. Account. Econ. 2005, 39, 163-197. [CrossRef] 
47. Kim, M.; Cheon, Y.; Lee, J. Insider trading and earnings management. Korean Account. Rev. 2010, 35, 1-37.

48. Botosan, C.A.; Plumlee, M.A. A re-examination of disclosure level and the expected cost of equity capital. J. Account. Res. 2002, 40, 21-40. [CrossRef]

49. Kim, J.B.; Yi, C.H. Ownership structure, business group affiliation, listing status and earnings management: Evidence from Korea. Contemp. Account. Res. 2006, 23, 427-464. [CrossRef] 